\title{
Prediction of Natural Volatile Organic Compounds Emitted by Bamboo Groves in Urban Forests
}

\author{
Yeji Choi (D), Geonwoo Kim *(D), Sujin Park (D), Eunsoo Kim and Soojin Kim \\ Forest Policy and Economics Department, Forest Welfare Division, National Institute of Forest Science, \\ Seoul 02455, Korea; usmile.choi@gmail.com (Y.C.); snowshoe@korea.kr (S.P.); euncarp2@gmail.com (E.K.); \\ kimsoojinsj@korea.kr (S.K.) \\ * Correspondence: bkim5020@korea.kr; Tel.: +82-02-961-2862
}

check for updates

Citation: Choi, Y.; Kim, G.; Park, S.; Kim, E.; Kim, S. Prediction of Natural Volatile Organic Compounds Emitted by Bamboo Groves in Urban Forests. Forests 2021, 12, 543. https:// doi.org/10.3390/f12050543

Academic Editors: Alan Ewert and Jillisa Overholt

Received: 23 March 2021

Accepted: 23 April 2021

Published: 27 April 2021

Publisher's Note: MDPI stays neutral with regard to jurisdictional claims in published maps and institutional affiliations.

Copyright: (c) 2021 by the authors. Licensee MDPI, Basel, Switzerland. This article is an open access article distributed under the terms and conditions of the Creative Commons Attribution (CC BY) license (https:// creativecommons.org/licenses/by/ $4.0 /)$.

\begin{abstract}
Due to the COVID-19 outbreak, people in countries around the world including the United Kingdom, Denmark, Canada, and South Korea are seeking physiological and psychological healing by visiting forests as stay-at-home orders continue. NVOCs (natural volatile organic compounds), a major healing factor of forests, have several positive effects on human health. This study specifically researched the NVOC characteristics of bamboo groves. This study revealed that $\alpha$-pinene, 3-carene, and camphene were observed to emit the most, and the largest amount of NVOC emitted was seen during the early morning and late afternoon within bamboo groves. Furthermore, NVOC emission was found to have normal correlations with temperature and humidity, and inverse correlations with solar radiation, PAR (photosynthetically active radiation), and wind speed. A regression analysis conducted to predict the effect of microclimate factors on NVOC emissions resulted in a regression equation with $82.9 \%$ explanatory power, finding that PAR, temperature, and humidity had a significant effect on NVOC emission prediction. In conclusion, this study investigated NVOC emission of bamboo groves, examined the relationship between NVOC emissions and microclimate factors, and derived a prediction equation of NVOC emissions to figure out bamboo groves' forest healing effects. These results are expected to provide a basis for establishing more effective forest healing programs in bamboo groves.
\end{abstract}

Keywords: NVOC; phytoncide; bamboo grove; monoterpene; microclimate; regression analysis

\section{Introduction}

Attention restoration theory, claimed by Stephen and Rachel Kaplan, explained that humans, who have grown tense due to continuous exposure to artificial environments, instinctively want to visit nature [1,2]. They argued that excessive "attention fatigue," caused by external environmental and internal psychological factors, are restored by the friendly "restorative environment" within forests, which makes them feel comfortable. This theory is further highlighted by the COVID-19 pandemic: due to the COVID-19 outbreak, people around the world were forced to minimize social contact through remote-working and online classes; thus, their time at home significantly increased [3,4]. Additionally, due to social distancing policies, interactions with family and friends were restricted, and the privilege to visit indoor locations that allow one to engage with leisure activities was now forfeit [4]. Instead of these places, parks and forests have been spotlighted as sites of recreation and healing [5-7]. As the time of home-based isolation increased, a higher rate of negative emotions such as depression, anxiousness, and loneliness were reported, which led to individuals choosing to visit forests and parks to relieve themselves of mental stressors [6,8]. According to a study conducted, in Korea, the big data analyzed showed that as people are getting tired of the prolonged COVID-19 situation, the demand for immunity improvement and healing through the therapeutic effects of phytoncide emitted by forests is increasing [9]. Since the first half of 2020, when COVID-19 began to spread worldwide, visitors to parks and forests have sharply increased [6]. The visiting population also became 
much more diverse compared to prior years, i.e., younger individuals and families with children were observed more frequently. As such, due to the global pandemic, forest and nature visitation continues to rise due to its' promotion of physical and psychological health.

As previously mentioned, Stephen and Rachel Kaplan argue that various studies have already demonstrated the ability of forests to promote diverse physiological and psychological health conditions. These forest healing effects include olfactory, visual, and socio-environmental; among which the most typically observed are the olfactory effects through phytoncide emitted by trees [10-14]. Phytoncide, a complex mixture of chemicals, secreted by trees to protect themselves from external harmful factors, is a representative healing factor in nature. Phytoncide can be called as a NVOC (natural volatile organic compound), and terpenes, a class of chemicals that are present in the phytoncide mixture, are found within it. Terpenes are notable for benefitting people's health when exposed to the atmosphere where it is scattered. Phytoncide is beneficial to both physiological and psychological health [15-21]. Phytoncide enhances NK cell (natural killer cell) activities [15], has antioxidant and antibacterial effects [16], and is known to reduce blood pressure, pulse rate, and cortisol levels [17-19]. Besides these physiological benefits, it also reduces stress and improves one's mood [17,19-21]. Since NVOC has different emissions and compositions depending on the tree's species, several studies have conducted experiments attempting to link specific tree species and natural environments with their corresponding forest healing effects.

Under these circumstances, several researchers began to pay attention to the effects of phytoncide emissions, focusing on physical health while also studying the economic and environmental benefits of bamboo. Currently, more than 1500 species of bamboo inhabit 22 million hectares of land worldwide, and research has been conducted to find out the effects of forest healing among different bamboo species. Observation of 12 various BVOC (biogenic volatile organic compound) emissions showed that they significantly differed between bamboo species [22]. According to the study that investigated steam extract of Phyllostachys species, it was found to be mainly comprised of monoterpenes, which are well known for various health benefits [23]. Furthermore, the study also revealed that Phyllostachys pubescens is said to have more significant anticancer and antioxidant effects than other species; therefore, it could be used as a natural anticancer and antioxidant factor in the future [23]. The high concentration of phytoncide emissions from bamboo groves has been proven to have a significant effect on reducing blood pressure, enhancing the immune system, and increasing the ability to concentrate through activation of brain waves; it is also effective in decreasing anxiety [24-26].

As such, several prior studies have demonstrated that many people are visiting forests to benefit from its healing effects, and bamboo groves have excellent forest healing environments [22-27]. However, while existing studies have been actively studying phytoncide diffusion characteristics of coniferous and broadleaf forests, analysis of the NVOC characteristics with a focus on bamboo groves is lacking. Furthermore, research that analyzes the relationships between microclimate environments and bamboo groves is rarer. One must recognize that it is essential to understand the characteristics of NVOC emission in bamboo groves and the factors affecting its emission in order to enhance the forest healing effects for bamboo grove visitors. Accordingly, this study revealed NVOC emission characteristics and diurnal patterns of Phyllostachys pubescens groves and proved correlation between various microclimate environment factors. In addition, to address the difficulty of regularly measuring NVOC and microclimate data over a wide range of forests for a long term, we established a prediction equation for emissions from bamboo groves through regression analysis. 


\section{Materials and Methods}

2.1. Study Site

The study was conducted at the National Institute of Forest Science's Gajwa Research Forest in the southern part of Jinju City, Gyeongsangnam-do in South Korea (Figure 1). Its geographical location is $35^{\circ} 9^{\prime} 37.4652^{\prime \prime} \mathrm{N}, 128^{\circ} 6^{\prime} 17.1504^{\prime \prime}$ E. The Gajwa Research Forest is located at $116.8 \mathrm{~m}$ above sea level and covers 27 hectares. The forest has three different kinds of bamboo groves, namely, Phyllostachys bambusoides, Phyllostachys nigra var. henonis, and Phyllostachys pubescens, the latter of which is the primary species of this study. It also contains the largest variety of bamboo among conservation centers in Korea with a total of 126 different species. It is currently the only center that conducts research on bamboo groves in Korea, and it serves as an important urban forest in Jinju city. As shown in Figure 1, there were three measurement points: A, B, and C, which were the three different experiment sites within the Phyllostachys pubescens grove. These letter designations allowed the team to reduce potential measurement errors while collecting data. The experiment sites were dense bamboo groves, consisting only of a single species: Phyllostachys pubescens. As a public park, it was under constant management, and no understory vegetation were found. The total length from point $A$ to point $C$ is about $200 \mathrm{~m}$.

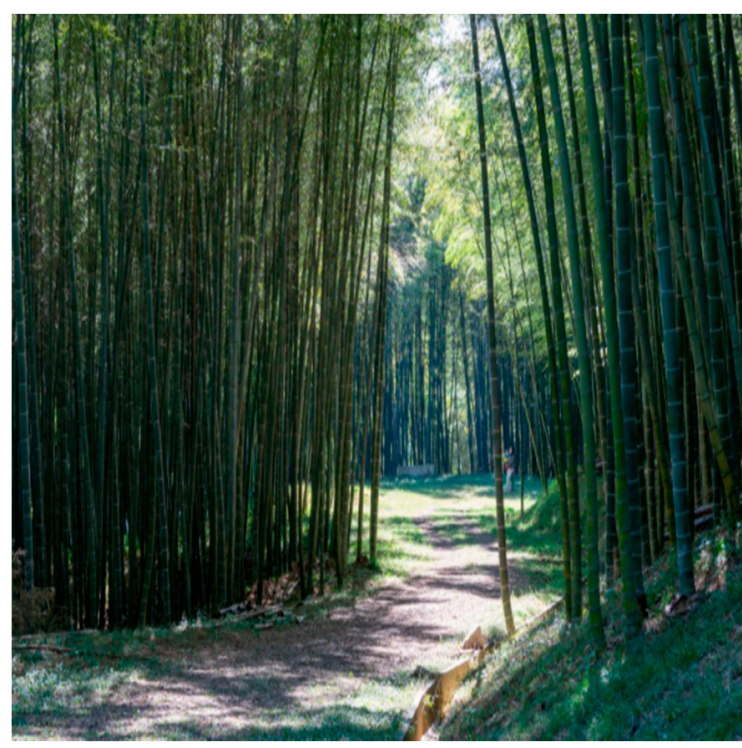

(a)

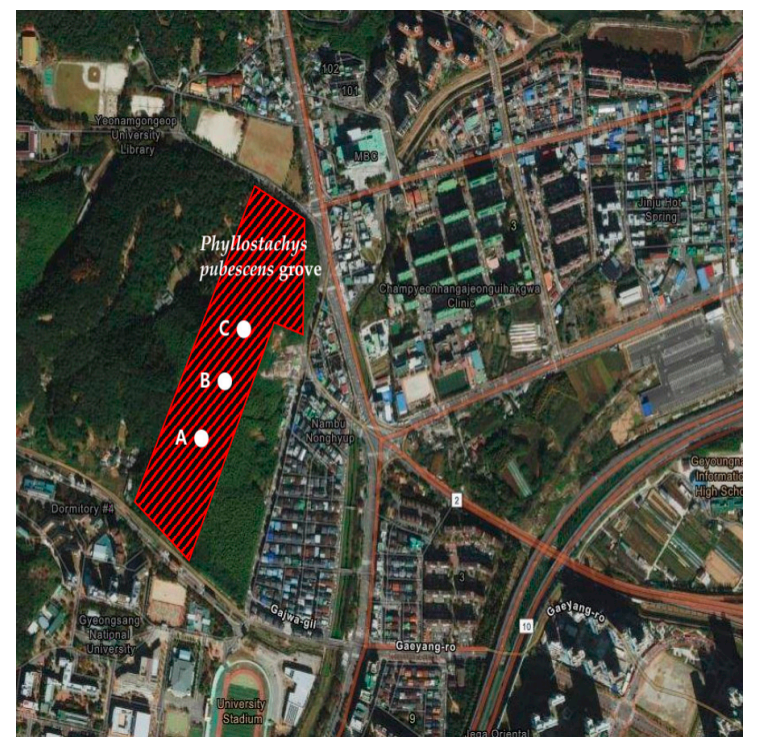

(b)

Figure 1. Figures of study sites: (a) Gajwa Phyllostachys pubescens grove; (b) NVOC measurement points (shaded area is Phyllostachys pubescens groves, and points A, B, and C are shown in the figure).

\subsection{Measurement Methods}

In order to proceed with this research, we assessed NVOC concentrations and microclimate environment. NVOC and microclimate environment data were collected in three different points in the Phyllostachys pubescens grove (points A, B, and C), as shown in Figure 1. Instead of measuring at a single point in the forest, which can be greatly influenced by external factors, the analysis was conducted with data measured at three different points to reduce errors and observe overall changes in the NVOC compounds and microclimate factors of the forest. Samples were measured once every hour during the experimental days on April to August of 2019, three different experiment days in total. Measurement factors are shown in Table 1, and a total of 17 NVOC compounds were selected out of 21 detected NVOC compounds. Four compounds, namely, trans-caryophyllene, pulegone, cedrol, and humulene, were excluded because the concentrations were too small, and therefore most collected samples could not detect them. 
Table 1. NVOCs and microclimate environment measurement factors.

\begin{tabular}{cc}
\hline NVOCs & Microclimate Environment \\
\hline 3-carene, borneol, bornyl acetate, & air humidity, air temperature, \\
camphene, camphor, d-limonene, & soil temperature, soil humidity, \\
eucalyptol, menthol, p-cymene, & gust speed, par (photosynthetically active \\
phellandrene, sabinene, $\alpha$-pinene, & radiation), solar radiation, \\
$\alpha$-terpinene, $\alpha$-terpinolene, $\beta$-myrcene, & wind speed \\
$\beta$-pinene, $\gamma$-terpinene & \\
\hline
\end{tabular}

\subsubsection{NVOCs (Natural Volatile Organic Compounds)}

NVOCs were measured on three different days between April and August of 2019. Of the three experimental days, one session collected NVOCs for a full $24 \mathrm{~h}$, and the other two sessions collected NVOCs from morning (9:00) to sunset (17:00). This was done to create data samples that focused on the time periods when visitation was highest. The study sites were arranged in a circle at $50 \mathrm{~m}$ intervals, according to geographical characteristics. In consideration of the vegetation characteristics, five pumps were installed at each point of the study site. The samples were collected using the adsorption tube process. Adsorption was performed using tubes loaded with Tenax TA $(150 \mathrm{mg})$ from Markes (Sacramento, CA, USA). NVOC was measured with a $\mu \mathrm{g} / \mathrm{m}^{3}$ unit, and $\mathrm{m}^{3}$ indicates the volume of the surrounding environment of the measurement sites. The total air volume of $9 \mathrm{~L}$, collected over an hour, was converted into $\mathrm{m}^{3}$, and detailed description is shown below.

The sample capture system was a mini pump (MP-30KN, Sibata, Japan), and the calibration was preceded by a measurement of the adsorption error before the flow meter was used. At a flow rate of $150 \mathrm{~mL} / \mathrm{min}$, a total volume of 9L of NVOC was collected. A prior study focusing on the sampling amount, conducted to make NVOC measurements in the forest more accurate and efficient, found the most efficient results in $9 \mathrm{~L}$ compared to when the air volumes were $1,3,6,9,12,24$, and $48 \mathrm{~L}$; therefore, this study was also conducted with an air volume of 9L [28]. The sampling equipment was set up on a tripod, $1.5 \mathrm{~m}$ off the ground, and the average value was determined by repeating this process at each site. During the experiment, disposable polyethylene gloves and antibacterial masks were used to avoid artificial errors when in contact with the tube. After sampling, the sample tubes were held at a temperature below $4{ }^{\circ} \mathrm{C}$ for $48 \mathrm{~h}$ before being analyzed (Table 2). In order to reduce potential error, we also reflected the value of the tubes collected, without filling Tenax TA inside.

Table 2. The conditions for the operating parameters for NVOC.

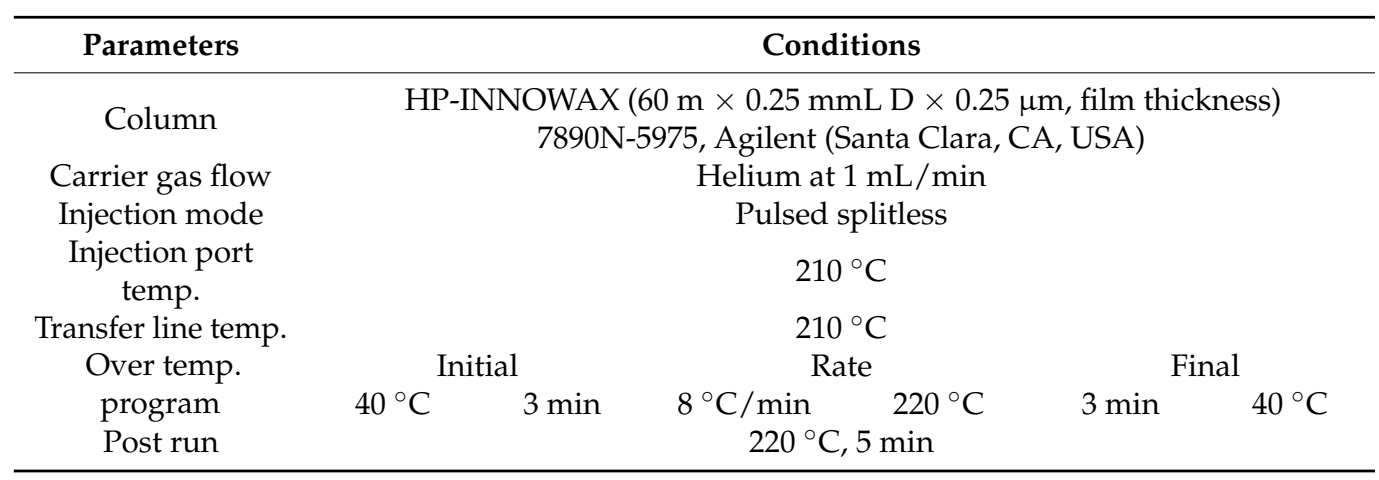

A gas chromatography mass spectrometer (7890N-5975, Agilent, Santa Clara, CA, USA) with a thermal desorption device was used to perform qualitative and quantitative analyses on the samples (GC-MSD, Gerstel TDS, Gerstel, Germany). The substances adsorbing in the adsorption tube was concentrated in a low temperature cryofocusing system, which took high-purity helium gas from a thermal desorption device at a rate of $1 \mathrm{~mL} / \mathrm{min}$. The system desorbed the gas, at $210{ }^{\circ} \mathrm{C}$ for $3 \mathrm{~min}$, while maintaining a 
temperature of $-30{ }^{\circ} \mathrm{C}$. The compounds were then heated at $220{ }^{\circ} \mathrm{C}$ for $3 \mathrm{~min}$ before being injected into a GC spectrometer and detected with an MSD.

\subsubsection{Microclimate Environment}

In terms of locational environment, the site's direction and slope were calculated. The physical features of the site environment were reported at $5 \mathrm{~min}$ intervals using a portable multifunction meter (HOBO-U23 V2, Onset, Bourne, MA, USA). Solar radiation sensors (S-LIB-M003, Onset, Bourne, MA, USA) and photosynthetically active radiation sensors (S-LIA-M003, Onset, USA) were positioned in the same position and tracked during the experiment.

A wind monitoring sensor (wind monitor O5103-45, R.N.Y., Logan, UT, USA) was also mounted in consideration of the geological features in order to obtain wind direction and velocity data at the designated site. The meter was set up in equilibrium at a height of $1.5 \mathrm{~m}$ on a tripod about $5 \mathrm{~m}$ from a mini pump, and the digitalized measurement results were saved and then converted for the study. The HOBO-ware Pro software was used to evaluate the findings (Onset, USA). To minimize potential measurement errors, we excluded the data, which were saved $5 \mathrm{~min}$ before and after each measurement, from the study. This study measured all the associated microclimate factors such as wind speed, gust speed, air temperature, and soil temperature. This was because, in the forest, the values may vary significantly depending on the forest and site stand conditions, even among the associated microclimate factors. In addition, it was to identify microclimate factors that were physically and quantitatively detectable. Since this study measured microclimate factors every $10 \mathrm{~min}$, both wind speed and gust speed were measured to observe changes occurring in a short period.

\subsubsection{Calibration Curve}

There are a few measures that can be used to validate the analysis device as well as the procedures. The calibration curve was drawn using 20 species of standard materials such as $\alpha$-pinene and $\beta$-pinene. A majority of the materials have a linearity greater than 0.997 by using the calibration curve to calculate each element's mass number and the square of its rate of diluting standard materials. For example, $\alpha$-pinene $\left(R^{2}=0.997\right)$, $\beta$-pinene $\left(R^{2}=0.998\right)$, and d-limonene $\left(R^{2}=0.999\right)$. Experiments conducted with these materials have a high level of reproducibility in terms of the linear correlation coefficient, making them ideal for research.

\subsection{Analysis Methods}

The analysis was conducted by using R 4.0.4 and RStudio. "lmtest", "gvlma", "lm.beta", and other R packages were used for the analysis. Data were collected from 17 NVOC compounds and 8 microclimate indicators shown in Table 1, with 259 and 1403 samples, respectively (Figure 2). The data were preprocessed and used for statistical analysis and TNVOC (total NVOC) results, which can represent 17 NVOC compounds, and were also used for analysis. The data preprocessing included data integration that combined the observed data from experiment sites A, B, and C, as well as data cleaning to remove missing values.

To identify the characteristics of NVOC emission within bamboo groves, we examined 17 NVOC substances for average daily emission concentrations. Furthermore, the main NVOC emission elements of bamboo groves were identified by calculating the proportion of each substance to the TNVOC emissions. In addition, to find out the trends of TNVOC and eight microclimate elements during a day, we observed diurnal patterns of each element, and the pattern was divided by phase where the changes were significant. 


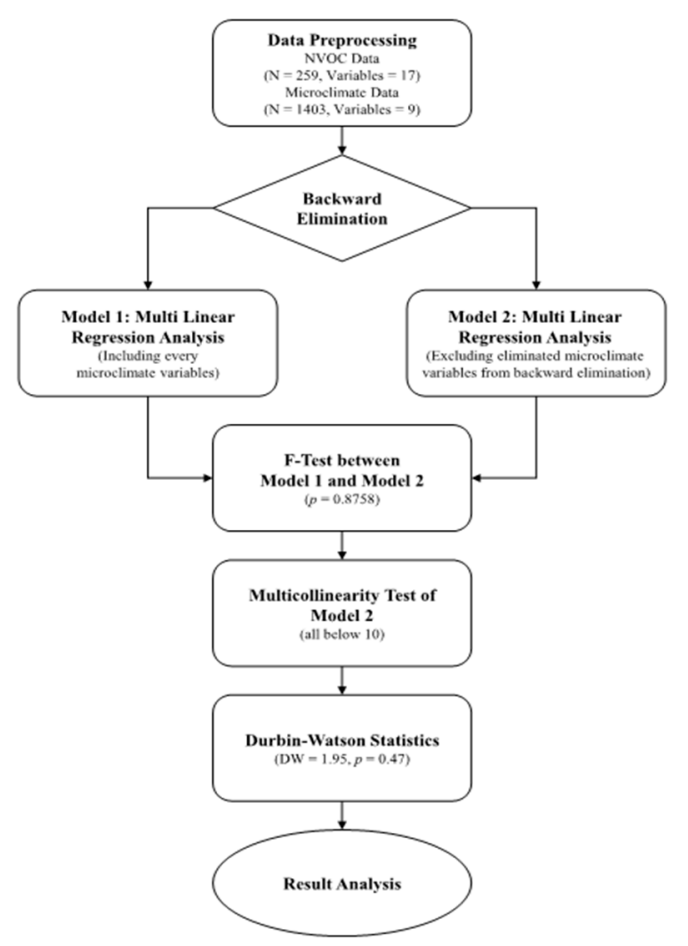

Figure 2. Flow diagram of regression analysis process. DW is the Durbin-Watson test statistic value.

In order to find out the effect of microclimate factors on NVOC emissions from bamboo groves, we conducted multiple regression analyses using the "backward elimination" method. The first model did not proceed with backward elimination, but performed a multiple regression analysis, including a total of eight, all microclimate indicators. The second model used the backward elimination method to perform multiple regression analysis. After building these two models, the F-test was conducted to prove that the removed microclimate indicators had no statistically significant effect. To verify the multicollinearity of Model 2, we identified the VIF (variance inflation factor), which was shown below 10 in all indicators, proving that there was no strong correlation between the independent variables. Finally, the Durbin-Warson test was conducted to determine the presence of autocorrelation between the residuals. Accordingly, the results of this study were analyzed on the basis of the Model 2 multiple regression analysis presented above.

\section{Results}

\subsection{Characteristics of NVOCs at Bamboo Groves}

The amount of emissions by NVOC components of Phyllostachys pubescens groves can be found in Figure 3. The most emitted NVOC was $\alpha$-pinene $\left(0.69 \mu \mathrm{g} / \mathrm{m}^{3}\right)$, accounting for $27.3 \%$ of the total emissions. The second most emitted NVOC was 3-carene $\left(0.58 \mu \mathrm{g} / \mathrm{m}^{3}\right)$ at $23 \%$, while the third was camphene $\left(0.49 \mu \mathrm{g} / \mathrm{m}^{3}\right)$ at $19.7 \%$. The above three NVOCs accounted for $70 \%$ of the total NVOC emissions, which were overwhelmingly higher than other compounds. They were followed by camphor $\left(7 \%, 0.18 \mu \mathrm{g} / \mathrm{m}^{3}\right), \beta$-pinene $(6 \%$, $\left.0.15 \mu \mathrm{g} / \mathrm{m}^{3}\right)$, borneol $\left(3.6 \%, 0.09 \mu \mathrm{g} / \mathrm{m}^{3}\right)$, d-limonene $\left(2.7 \%, 0.07 \mu \mathrm{g} / \mathrm{m}^{3}\right)$, p-cymene $(2.2 \%$, $\left.0.06 \mu \mathrm{g} / \mathrm{m}^{3}\right)$, bornyl acetate $\left(1.9 \%, 0.05 \mu \mathrm{g} / \mathrm{m}^{3}\right)$, eucalyptol $\left(1.6 \%, 0.04 \mu \mathrm{g} / \mathrm{m}^{3}\right)$, $\beta$-myrcene $\left(1.1 \%, 0.03 \mu \mathrm{g} / \mathrm{m}^{3}\right)$, sabinene $\left(1.1 \%, 0.03 \mu \mathrm{g} / \mathrm{m}^{3}\right)$, menthol $\left(0.9 \%, 0.02 \mu \mathrm{g} / \mathrm{m}^{3}\right)$, $\gamma$-terpinene $\left(0.7 \%, 0.02 \mu \mathrm{g} / \mathrm{m}^{3}\right), \alpha$-terpinene $\left(0.4 \%, 0.01 \mu \mathrm{g} / \mathrm{m}^{3}\right)$, phellandrene $\left(0.4 \%, 0.01 \mu \mathrm{g} / \mathrm{m}^{3}\right)$, and $\alpha$-terpinolene $\left(0.3 \%, 0.01 \mu \mathrm{g} / \mathrm{m}^{3}\right)$. 


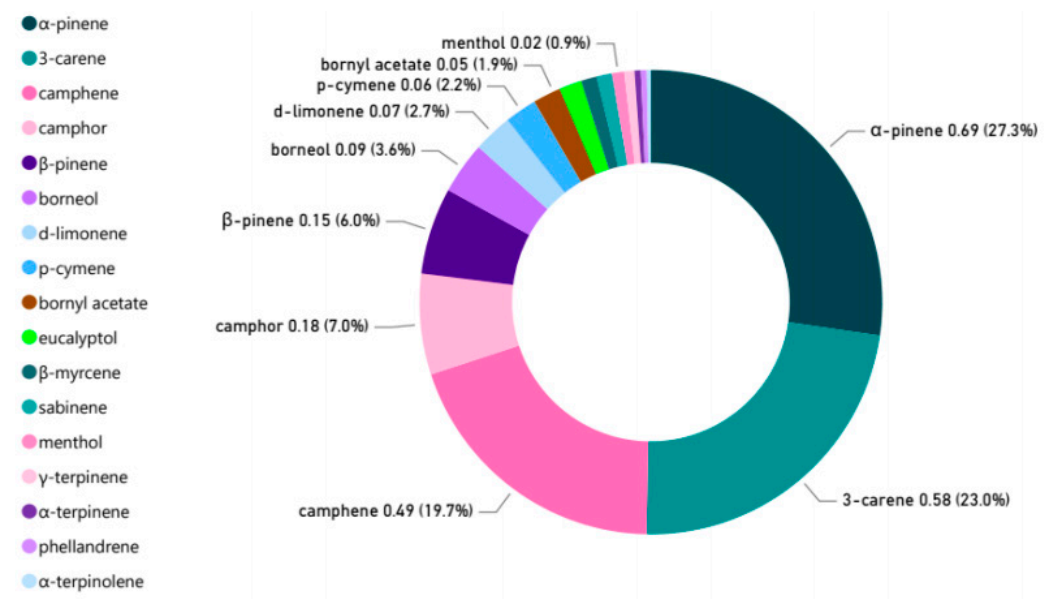

Figure 3. Emission analysis of bamboo groves by NVOC components.

\subsection{The Variations of NVOC Concentration}

The diurnal pattern between TNVOC emissions and microclimate factors is shown in Figure 4. The grayed-out region is the TNVOC emission by time, and the six broken line graphs show the change of each microclimate factor. Soil humidity and gust speed were excluded, which had low significance and tendency. For soil humidity, the difference between maximum and minimum observations were insignificant to 0.006 , making it difficult to compare changes in soil humidity and changes in TNVOC. Additionally, for gust speed, the maximum value was $2.0 \mathrm{~m} / \mathrm{s}$, and the average value was $0.8 \mathrm{~m} / \mathrm{s}$, which was too low to be observed as gust speed. The changes in time of other six microclimate indicators were examined by dividing them into four phases. The first phase included a change from 5:00 to 7:00. The TNVOC, which peaked at 5:00, decreased with a drop in temperature. Humidity, soil temperature, and wind speed did not show significant changes. PAR and solar radiation tended to increase in reverse from 5:00 to 7:00 when TNVOC dropped. The conflicting trends between TNVOC and PAR and solar radiation were more pronounced in the second phase. The TNVOC increased slightly from 7:00 to 8:00 but decreased significantly from 8:00 to 10:00 in the second phase. This was in contrast to PAR, solar radiation, and wind speed, which showed an increasing trend from 8:00 to 10:00. Temperature and humidity showed a downward change, such as TNVOC, and soil temperature did not show much change. At noon, before phase 3 , all indicators, except soil temperature, showed a trend of slightly rising and then decreasing again. After 12:00, TNVOC decreased and maintained, but increased significantly from 17:00 to 19:00. This was the third phase, with temperature and humidity also showing a tendency to increase, while PAR, solar radiation and wind speed were reduced in reverse. Soil temperature still showed minimal changes. The TNVOC peaked at 19:00 and then declined until 20:00 but rose sharply from 20:00 to 22:00, which was the fourth phase. Temperature rose slightly in the fourth phase, and other indicators showed no significant changes. Moreover, TNVOC recorded its highest daily emission at 23:00. Of the 17 types of NVOCs included in the TNVOC, 16 compounds were found at high levels in the early morning and late afternoon, similar to the diurnal pattern of the TNVOC. On the other hand, $\beta$-myrcene, as opposed to TNVOC, was detected at a low concentration early in the morning and at the highest concentration during the day; however, the opposite trend of $\beta$-myrcene did not significantly affect TNVOC analysis, since its emission was $0.03 \mu \mathrm{g} / \mathrm{m}^{3}$, which was about $1 \%$ of TNVOC. 


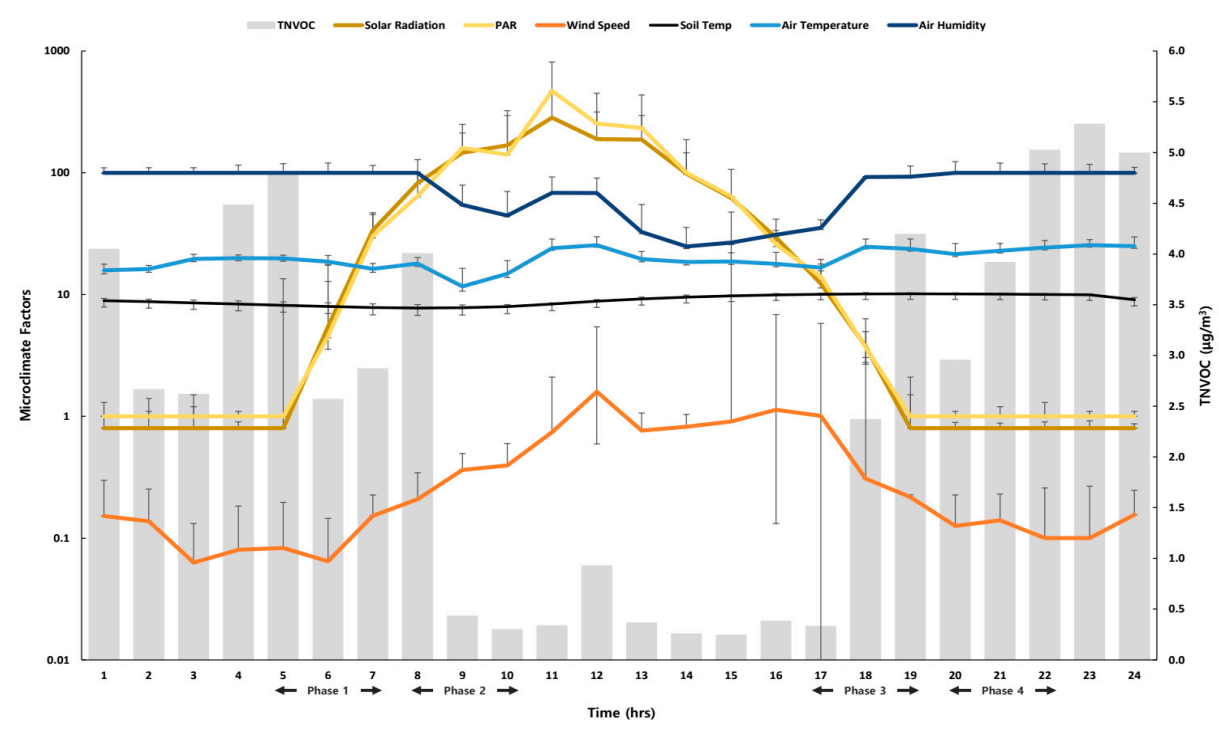

Figure 4. Diurnal graph of TNVOC (Total Natural Volatile Organic Compounds) and microclimate factors. The error bar indicates standard deviation of each indicators. The $x$-axis represents the time from 0:00 to 24:00 with four phases. The $y$-axis on the left represents the value of each microclimate factor, and the $y$-axis on the right represents the TNVOC value. Units of each microclimate factors: solar radiation $\left(\mathrm{W} / \mathrm{m}^{2}\right)$, PAR $(\mathrm{uE})$, wind speed $(\mathrm{m} / \mathrm{s})$, soil temperature and air temperature $\left({ }^{\circ} \mathrm{C}\right)$, and air humidity (\% rh).

On the basis of this trend graph analysis, we show in Figure 5 the Pearson correlation between TNVOC and the microclimate factors. As previously identified in the trend graph, TNVOC had a strong inverse correlation with solar radiation, PAR, and wind speed, and a strong normal correlation with air temperature and air humidity; however, soil temperature was not shown to have a significant correlation with TNVOC.

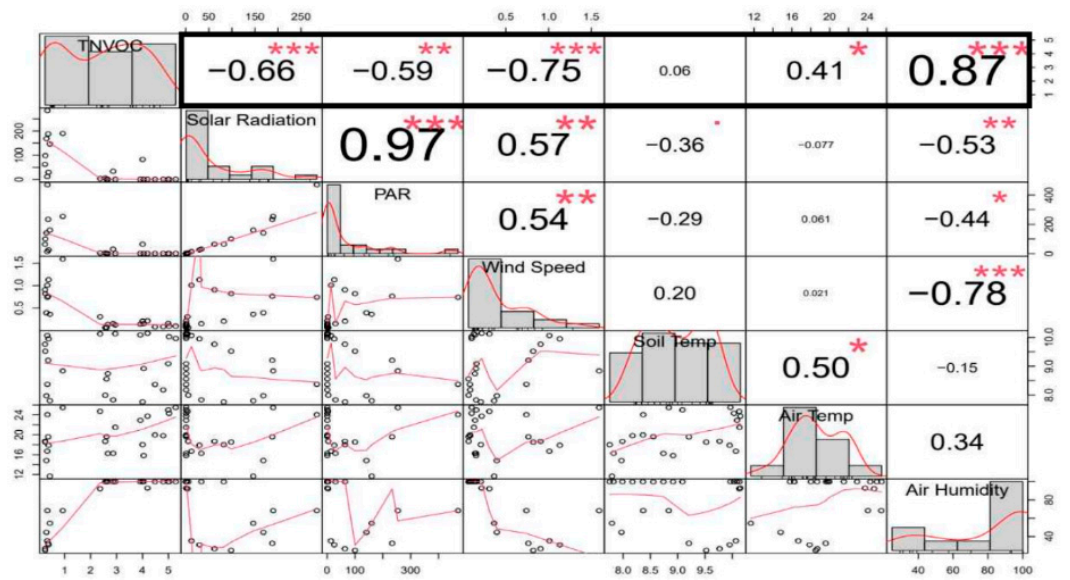

Figure 5. Pearson correlations between TNVOC and microclimate factors. ${ }^{*} p<0.05,{ }^{* *} p<0.01{ }^{* * *} p<0.001$.

\subsection{NVOCs and Physical Environments of Bamboo Groves}

To investigate the effects of microclimate factors on NVOC emissions, we conducted multiple regression analyses (Figure 2). TNVOC was established as a dependent variable, eight microclimate factors as independent variables, and the backward elimination method was adopted. The multiple regression analysis including all eight independent variables was set to Model 1, and multiple regression analysis excluding variables removed through backward elimination was set to Model 2. Regression results from Model 1 and Model 2 can be found in Table 3. A total of four microclimate factors were excluded from the backward elimination, in order of gust speed, soil temperature, solar radiation, and soil humidity. As is shown in Table 3, PAR and wind speed had a negative relationship with 
TNVOC, and air temperature and air humidity had a positive relationship. Among them, PAR, air temperature, and air humidity were shown to be significantly related to TNVOC emissions. The significance probability of Model 2 was 0.000, indicating that the regression model was suitable, and the adjusted $R^{2}$ was 0.829 , which had sufficient explanatory power. Furthermore, multicollinearity tests demonstrated that all indicators had below 10 on VIF (variance inflation factor), and all explanatory variables in Model 2 were not highly linearly related. Finally, the D-W value obtained from the Durbin-Watson statistics was 1.95 , indicating that no autocorrelation existed between the residuals and that they were independent of each other (Table 4).

Table 3. Multiple regression results of Model 1 and Model 2.

\begin{tabular}{|c|c|c|c|c|c|c|c|c|}
\hline & Indicators & Estimate & $\begin{array}{l}\text { Std. } \\
\text { Error }\end{array}$ & $t$-Value ${ }^{1}$ & $p^{2}$ & $\begin{array}{c}\text { Adjusted } \\
R^{2}\end{array}$ & $F^{3}$ & $p^{4}$ \\
\hline \multirow{9}{*}{ Model 1} & (Intercept) & 8.920 & 20.254 & 0.440 & 0.666 & \multirow{9}{*}{0.796} & \multirow{9}{*}{12.240} & \multirow{9}{*}{$0.000^{* * *}$} \\
\hline & Solar Radiation & 0.008 & 0.016 & 0.510 & 0.618 & & & \\
\hline & PAR & -0.010 & 0.009 & -1.095 & 0.291 & & & \\
\hline & Wind speed & -1.078 & 1.154 & -0.934 & 0.365 & & & \\
\hline & Gust speed & -0.039 & 1.300 & -0.030 & 0.976 & & & \\
\hline & Soil temp. & 0.022 & 0.672 & 0.033 & 0.974 & & & \\
\hline & Soil humidity & -80.648 & 174.771 & -0.461 & 0.651 & & & \\
\hline & Air temp. & 0.183 & 0.087 & 2.093 & 0.054 & & & \\
\hline & Air humidity & 0.026 & 0.022 & 1.163 & 0.263 & & & \\
\hline \multirow{5}{*}{ Model 2} & (Intercept) & -1.704 & 0.986 & -1.729 & 0.100 & \multirow{5}{*}{0.829} & \multirow{5}{*}{28.930} & \multirow{5}{*}{$0.000^{* * *}$} \\
\hline & PAR & -0.004 & 0.002 & -2.682 & $0.015^{*}$ & & & \\
\hline & Wind speed & -1.075 & 0.720 & -1.493 & 0.152 & & & \\
\hline & Air temp. & 0.135 & 0.051 & 2.626 & 0.017 * & & & \\
\hline & Air humidity & 0.029 & 0.011 & 2.761 & $0.012 *$ & & & \\
\hline
\end{tabular}

${ }^{*} p<0.05,{ }^{* * *} p<0.001 .{ }^{1}$ Coefficient $t$-value. ${ }^{2}$ Calculated probability of each independent variable. ${ }^{3}$ Test statistic from the F-test.

${ }^{4}$ Calculated probability of each model.

Table 4. Variance inflation factor (VIF) and Durbin-Watson statistics results of Model 2.

\begin{tabular}{ccccccccc}
\hline Model & \multicolumn{4}{c}{ Variance Inflation Factor } & \multicolumn{3}{c}{ Durbin-Watson Statistics } \\
\hline \multirow{2}{*}{ Model 2 } & PAR & Wind Speed & Air Temp. & Air Humidity & Lag & Auto-correlation & DW ${ }^{1}$ & $p$ \\
\cline { 2 - 23 } & 1.43 & 3.60 & 1.49 & 3.76 & 1 & -0.03 & 1.95 & 0.50 \\
\hline
\end{tabular}

${ }^{1} \mathrm{DW}$ is the Durbin-Watson test statistic value.

Accordingly, the variables that had the greatest impact on TNVOC emissions were seen to be PAR, air temperature, and air humidity. The regression equation for Model 2 is shown below.

$$
\begin{gathered}
\text { TNVOC }=-1.704+-0.004 \times(\text { PAR })-1.075 \times(\text { Wind Speed })+0.135 \times \\
(\text { Air Temperature })+0.029 \times(\text { Air Humidity })
\end{gathered}
$$

\section{Discussion}

This study aimed to discover the NVOC emission characteristics of bamboo groves and to build a model to predict the effects of microclimate elements on the NVOC emissions of bamboo groves. Prior studies have already demonstrated that microclimate factors affect NVOC emissions in various types of forests, especially the NVOC emission characteristics of broadleaf forests and coniferous forests. Despite this, not many studies have analyzed the NVOC distribution characteristics of bamboo groves and their association with microclimates. Although bamboo groves are widely distributed in East Asia, research predicting NVOC emissions within them remain rare. According to the existing prior studies mentioned earlier, bamboo groves provide diverse psychological and physiological health benefits including enhancing the immune system and cytotoxic effects $[22,24,26]$; 
therefore, an investigation into the effects of microclimate elements on the NVOC emissions of Phyllostachys pubescens groves, a specific type of bamboo grove, is necessary to better understand the positive effects that bamboo groves have on humans. Even though several studies have already demonstrated the effect of microclimate on NVOC emissions in forests, there is a need for a model to predict them since it is currently difficult to regularly measure NVOC emissions and microclimate changes across forests due to the changes they undergo over time. Accordingly, this study identified the type of monoterpene that is mainly emitted from bamboo groves, and the relationship between NVOC and microclimate factors in the bamboo groves. Lastly, this study established the NVOC emission prediction model through the regression analysis.

In this study, a total of 17 NVOCs were detected in the Phyllostachys pubescens grove: it was detected highest in the order of $\alpha$-pinene, 3-carene, camphene, camphor, and $\beta$-pinene. The above five substances have also been shown to be the main components of NVOC in several prior studies. Since there are not many studies that calculate the exact amount of each compound of NVOCs in bamboo groves, it is challenging to compare measured values of this study with other bamboo grove-related prior studies but, compared to prior studies that measured NVOCs emitted by different types of forests with the same measurement methods, the amount of NVOC compounds detected in this study was found to be similar or higher than the values of preceding studies [28,29]. In particular, $\alpha$-pinene, 3 -carene, and camphene accounted for $70 \%$ of the total emissions, with $\alpha$-pinene known to have anxiolytic, anti-inflammatory, antioxidant, and antiproliferative effects, while 3-carene is known to improve inflammatory conditions [14,30-33]. Finally, camphene was found to have antiproliferative, antioxidant, antinociceptive, and antihyperlipidemic effects, along with the ability to enhance metabolic activities [34-36]. As such, it has been revealed that major NVOCs emitted from bamboo groves have various healing effects. In addition, when checking diurnal patterns of NVOC emissions and microclimate factors in bamboo groves, TNVOC was the highest at 1:00 to 8:00 and 18:00 to 24:00, excluding daytime hours, and peaked at 23:00. Considering that the study period was from April to August, this is consistent with prior studies that proved that NVOC is produced the most in the morning and late afternoon during spring and summer [37-39]. Given the graph of diurnal pattern and Pearson correlation results, NVOC emissions showed strong inverse correlation with solar radiation, PAR, and wind speed, and strong normal relationship with temperature and humidity. This matches with previous studies that claimed correlation of radiation, wind speed, temperature, humidity, and NVOC emissions [37-42]. On the basis of these findings, this study conducted a multi-regression analysis to establish a model for NVOC prediction through microclimate factors. There were a total of four microclimate factors affecting TNVOC emission forecasts, namely, PAR, wind speed, air temperature, and air humanity. Air temperature, air humidity, and wind speed were also included in prior studies that derived TNVOC prediction regression for different types of forests, meaning that this study found the effect of PAR on TNVOC prediction in addition to the above three factors, and thus it is expected to be useful for bamboo groves' TNVOC prediction [7,29].

It is important to note that this study had several limitations. First, this regression was derived from data measured from a Phyllostachys pubescens grove in Jinju, South Korea, and the threshold remains that predictive accuracy can be reduced in areas with different climates and different physical elements. Second, as many other factors besides microclimate elements can affect NVOC emissions of Phyllostachys pubescens groves, outside factors also need to be considered including soil nutrient availability, herbivore damage on plants, and microbial interactions. Third, it is limiting that the NVOC and microclimate data of Phyllostachys pubescens groves were not measured continuously, but rather only on three instances, across a short time-period; thus, in subsequent studies, data collection on bamboo groves in varied regions, with more frequent observations and across a longer term, will allow for a more expansive study. Furthermore, since this study identified four major microclimate factors that affect NVOC emissions in bamboo groves, it is expected that further studies will be able to consider these four specific microclimate factors in 
their research, instead of all microclimate factors. Lastly, researching about how these four microclimate factors affect other types of forests will also further expand this field of research.

During this COVID-19 pandemic, people are staying in their homes longer than before, and thus an interest in healthcare is rapidly increasing, and an increasing number of people are seeking healing elements in parks and forests near their homes as previously mentioned; therefore, forests and the natural environments that provide various healing elements, which promote health conditions, are drawing significant attention. However, there is still a lack of research on the specific mechanisms of what factors in forests and green areas affect health improvement, but this study could be used as a basis for identifying these mechanisms, since it identified the relationship between NVOC, one of the forest healing elements, and microclimate factors, along with deriving a regression equation to predict NVOC emissions in bamboo groves.

\section{Conclusions}

This study was conducted to identify the NVOC emission characteristics of bamboo groves with abundant forest healing elements and their relationship to microclimate factors while building a prediction equation for NVOC emissions from bamboo groves. This study, conducted in Phyllostachys pubescens groves in Jinju, Gyeongsangnam-do, South Korea, was analyzed on the basis of a total of 259 NVOC samples and 1403 microclimate data. A total of 17 types of NVOC were detected, and the relationship with eight microclimate factors was examined. Of the 17 NVOCs detected, $\alpha$-pinene, 3 -carene, and camphene were found at high levels, with these three monoterpenes accounting for $70 \%$ of the total NVOC emissions. A review of diurnal NVOC emission patterns, in the bamboo groves, confirmed that the amount of TNVOC was detected high in the early morning and late afternoon. These patterns of TNVOC emissions showed strong normal correlations with air temperature and air humidity, as well as strong inverse correlations with solar radiation, PAR, and wind speed. Soil temperature was shown to have much correlation with TNVOC emissions. Finally, to establish a model for predicting NVOC emissions from bamboo groves, we conducted multiple regression analyses on the basis of changes in NVOC emissions and microclimate factors. The selected regression equation included a total of four microclimate factors and was found to have a high explanatory power of $82.9 \%$. The above findings and prediction equation will serve as a foundational insight regarding NVOC emissions of bamboo groves, spaces for forest healing, and these results could be used as a basis for providing better forest-based healing services for citizens.

Author Contributions: Conceptualization, Y.C., G.K., and S.P.; methodology, E.K.; software, Y.C.; validation, Y.C., E.K., and S.K.; formal analysis, Y.C.; investigation, E.K. and S.K.; resources, G.K. and S.P.; data curation, G.K.; writing—original draft preparation, Y.C.; writing—review and editing, G.K. and S.P.; visualization, S.K.; supervision, G.K.; project administration, S.P. All authors have read and agreed to the published version of the manuscript.

Funding: This research received no external funding.

Institutional Review Board Statement: Not applicable.

Informed Consent Statement: Not applicable.

Data Availability Statement: The data presented in this study are available on request from the corresponding author. The data are not publicly available since they are collected for internal research purposes of the National Institute of Forest Science, Republic of Korea.

Acknowledgments: We thank the anonymous reviewers for their constructive comments on the manuscript.

Conflicts of Interest: The authors declare no conflict of interest.

\section{References}

1. Kaplan, S. The Restorative Benefits of Nature: Toward an Integrative Framework. J. Environ. Psychol. 1995, 15, 169-182. [CrossRef] 
2. Hartig, T.; van den Berg, A.E.; Hagerhall, C.M.; Tomalak, M.; Bauer, N.; Hansmann, R.; Ojala, A.; Syngollitou, E.; Carrus, G.; van Herzele, A. Health Benefits of Nature Experience: Psychological, Social and Cultural Processes. In Forests, Trees and Human Health; Springer: Berlin/Heidelberg, Germany, 2011; pp. 127-168.

3. Ammar, A.; Brach, M.; Trabelsi, K.; Chtourou, H.; Boukhris, O.; Masmoudi, L.; Bouaziz, B.; Bentlage, E.; How, D.; Ahmed, M. Effects of COVID-19 Home Confinement on Eating Behaviour and Physical Activity: Results of the ECLB-COVID19 International Online Survey. Nutrients 2020, 12, 1583. [CrossRef] [PubMed]

4. Gostin, L.O.; Wiley, L.F. Governmental Public Health Powers during the COVID-19 Pandemic: Stay-at-Home Orders, Business Closures, and Travel Restrictions. JAMA 2020, 323, 2137-2138. [CrossRef]

5. Geng, D.C.; Innes, J.; Wu, W.; Wang, G. Impacts of COVID-19 Pandemic on Urban Park Visitation: A Global Analysis. J. For. Res. 2021, 32, 553-567. [CrossRef]

6. Derks, J.; Giessen, L.; Winkel, G. COVID-19-Induced Visitor Boom Reveals the Importance of Forests as Critical Infrastructure. For. Policy Econ. 2020, 118, 102253. [CrossRef]

7. KIM, G.; PARK, B.-J.; KOGA, S. Development of a Prediction Model for NVOC Concentration with Changing Microclimate in Camellia Japonica Temple Forest. Kyushu Univ. 2021, 66, 105-113.

8. Tull, M.T.; Edmonds, K.A.; Scamaldo, K.M.; Richmond, J.R.; Rose, J.P.; Gratz, K.L. Psychological Outcomes Associated with Stay-at-Home Orders and the Perceived Impact of COVID-19 on Daily Life. Psychiatry Res. 2020, 289, 113098. [CrossRef]

9. Ha, K.; Shin, W. Changes of the Forest Therapy Paradigm in the Post-Corona Era: Focusing on Analysis of News Search Words Related to Forest Therapy and COVID-19. J. Tour. Manag. Res. 2021, 25, 611-637.

10. Fong, K.C.; Hart, J.E.; James, P. A Review of Epidemiologic Studies on Greenness and Health: Updated Literature through 2017. Curr. Environ. Health Rep. 2018, 5, 77-87. [CrossRef]

11. Ulrich, R.S. Natural versus Urban Scenes: Some Psychophysiological Effects. Environ. Behav. 1981, 13, 523-556. [CrossRef]

12. James, P.; Banay, R.F.; Hart, J.E.; Laden, F. A Review of the Health Benefits of Greenness. Curr. Epidemiol. Rep. 2015, 2, 131-142. [CrossRef]

13. Hug, S.-M.; Hartig, T.; Hansmann, R.; Seeland, K.; Hornung, R. Restorative Qualities of Indoor and Outdoor Exercise Settings as Predictors of Exercise Frequency. Health Place 2009, 15, 971-980. [CrossRef]

14. Antonelli, M.; Donelli, D.; Barbieri, G.; Valussi, M.; Maggini, V.; Firenzuoli, F. Forest Volatile Organic Compounds and Their Effects on Human Health: A State-of-the-Art Review. Int. J. Environ. Res. Public Health 2020, 17, 6506. [CrossRef]

15. Li, Q.; Kobayashi, M.; Wakayama, Y.; Inagaki, H.; Katsumata, M.; Hirata, Y.; Hirata, K.; Shimizu, T.; Kawada, T.; Park, B.J. Effect of Phytoncide from Trees on Human Natural Killer Cell Function. Int. J. Immunopathol. Pharmacol. 2009, 22, 951-959. [CrossRef]

16. Abe, T.; Hisama, M.; Tanimoto, S.; Shibayama, H.; Mihara, Y.; Nomura, M. Antioxidant Effects and Antimicrobial Activites of Phytoncide. Biocontrol. Sci. 2008, 13, 23-27. [CrossRef]

17. Nam, E.-S.; Uhm, D.-C. Effects of Phytoncides Inhalation on Serum Cortisol Level and Life Stress of College Students. Korean J. Adult Nurs. 2008, 20, 697-706.

18. Kawakami, K.; Kawamoto, M.; Nomura, M.; Otani, H.; Nabika, T.; Gonda, T. Effects of Phytoncides on Blood Pressure under Restraint Stress in SHRSP. Clin. Exp. Pharmacol. Physiol. 2004, 31, S27-S28. [CrossRef]

19. Lee, J.; Park, B.-J.; Tsunetsugu, Y.; Ohira, T.; Kagawa, T.; Miyazaki, Y. Effect of Forest Bathing on Physiological and Psychological Responses in Young Japanese Male Subjects. Public Health 2011, 125, 93-100. [CrossRef]

20. Kim, C.-G.; Cho, M.-K.; Kim, J.-I. Effects of Phytoncide Aromatherapy on Stress, Symptoms of Stress and Heart Rate Variability among Nursing Students. J. Korean Biol. Nurs. Sci. 2012, 14, 249-257. [CrossRef]

21. Cheng, W.-W.; Lin, C.-T.; Chu, F.-H.; Chang, S.-T.; Wang, S.-Y. Neuropharmacological Activities of Phytoncide Released from Cryptomeria Japonica. J. Wood Sci. 2009, 55, 27-31. [CrossRef]

22. Melnychenko, A.N.; Rosenstiel, T.N. Biogenic Volatile Organic Compound Emissions from Bamboo: Exploring Patterns of Diversity across Species. J. Am. Bamboo Soc. 2015, 28, 1-9.

23. Kim, J.-S.; Lee, H.C.; Jo, J.-S.; Jung, J.Y.; Ha, Y.L.; Yang, J.-K. Evaluation of Antioxidant and Anticancer Activity of Steam Extract from the Bamboo Species. J. Korean Wood Sci. Technol. 2014, 42, 543-554. [CrossRef]

24. Hassan, A.; Tao, J.; Li, G.; Jiang, M.; Aii, L.; Zhihui, J.; Zongfang, L.; Qibing, C. Effects of Walking in Bamboo Forest and City Environments on Brainwave Activity in Young Adults. Evid. Based Complementary Altern. Med. 2018, 2018, 9653857. [CrossRef]

25. Ben-Zhi, Z.; Mao-Yi, F.; Jin-Zhong, X.; Xiao-Sheng, Y.; Zheng-Cai, L. Ecological Functions of Bamboo Forest: Research and Application. J. For. Res. 2005, 16, 143-147. [CrossRef]

26. Lyu, B.; Zeng, C.; Xie, S.; Li, D.; Lin, W.; Li, N.; Jiang, M.; Liu, S.; Chen, Q. Benefits of a Three-Day Bamboo Forest Therapy Session on the Psychophysiology and Immune System Responses of Male College Students. Int. J. Environ. Res. Public Health 2019, 16, 4991. [CrossRef]

27. Shin, W.S.; Kim, J.-J.; Lim, S.S.; Yoo, R.-H.; Jeong, M.-A.; Lee, J.; Park, S. Paradigm Shift on Forest Utilization: Forest Service for Health Promotion in the Republic of Korea. Net. J. Agric. Sci 2017, 5, 53-57. [CrossRef]

28. Geonwoo, K.I.M.; PARK, B.-J.; Joung, D.; YEOM, D.-G.; Shinya, K. Primary Concentration Measurements of Natural Volatile Organic Compounds in Atmosphere Using the Headspace Solid-Phase Microextraction Method within the Forest. J. Fac. Agr. Kyushu Univ. 2015, 60, 471-476.

29. Kim, G.; Park, S.; Kwak, D. Is It Possible to Predict the Concentration of Natural Volatile Organic Compounds in Forest Atmosphere? Int. J. Environ. Res. Public Health 2020, 17, 7875. [CrossRef] 
30. Yoshida, N.; Takada, T.; Yamamura, Y.; Adachi, I.; Suzuki, H.; Kawakami, J. Inhibitory Effects of Terpenoids on Multidrug Resistance-Associated Protein 2-and Breast Cancer Resistance Protein-Mediated Transport. Drug Metab. Dispos. 2008, 36, 1206-1211. [CrossRef]

31. Khoshnazar, M.; Bigdeli, M.R.; Parvardeh, S.; Pouriran, R. Attenuating Effect of A-pinene on Neurobehavioural Deficit, Oxidative Damage and Inflammatory Response Following Focal Ischaemic Stroke in Rat. J. Pharm. Pharmacol. 2019, 71, 1725-1733. [CrossRef]

32. Rahbar, I.; Abbasnejad, M.; Haghani, J.; Raoof, M.; Kooshki, R.; Esmaeili-Mahani, S. The Effect of Central Administration of Alpha-pinene on Capsaicin-induced Dental Pulp Nociception. Int. Endod. J. 2019, 52, 307-317. [CrossRef]

33. Bottoni, M.; Milani, F.; Colombo, L.; Nallio, K.; Colombo, P.S.; Giuliani, C.; Bruschi, P.; Fico, G. Using Medicinal Plants in Valmalenco (Italian Alps): From Tradition to Scientific Approaches. Molecules 2020, 25, 4144. [CrossRef]

34. Girola, N.; Figueiredo, C.R.; Farias, C.F.; Azevedo, R.A.; Ferreira, A.K.; Teixeira, S.F.; Capello, T.M.; Martins, E.G.; Matsuo, A.L.; Travassos, L.R. Camphene Isolated from Essential Oil of Piper Cernuum (Piperaceae) Induces Intrinsic Apoptosis in Melanoma Cells and Displays Antitumor Activity in Vivo. Biochem. Biophys. Res. Commun. 2015, 467, 928-934. [CrossRef]

35. Quintans-Júnior, L.; Moreira, J.C.; Pasquali, M.A.; Rabie, S.; Pires, A.S.; Schröder, R.; Rabelo, T.K.; Santos, J.; Lima, P.S.; Cavalcanti, S.C. Antinociceptive Activity and Redox Profile of the Monoterpenes. Int. Sch. Res. Not. 2013, 2013, 459530.

36. Vallianou, I.; Peroulis, N.; Pantazis, P.; Hadzopoulou-Cladaras, M. Camphene, a Plant-Derived Monoterpene, Reduces Plasma Cholesterol and Triglycerides in Hyperlipidemic Rats Independently of HMG-CoA Reductase Activity. PLoS ONE 2011, 6, e20516. [CrossRef]

37. Bach, A.; Yáñez-Serrano, A.M.; Llusià, J.; Filella, I.; Maneja, R.; Penuelas, J. Human Breathable Air in a Mediterranean Forest: Characterization of Monoterpene Concentrations under the Canopy. Int. J. Environ. Res. Public Health 2020, 17, 4391. [CrossRef] [PubMed]

38. Chen, Y.-J.; Cheng, S.-S.; Chang, S.-T. Monitoring the Emission of Volatile Organic Compounds from the Leaves of Calocedrus Macrolepis Var. Formosana Using Solid-Phase Micro-Extraction. J. Wood Sci. 2010, 56, 140-147. [CrossRef]

39. Llusia, J.; Peñuelas, J.; Seco, R.; Filella, I. Seasonal Changes in the Daily Emission Rates of Terpenes by Quercus Ilex and the Atmospheric Concentrations of Terpenes in the Natural Park of Montseny, NE Spain. J. Atmos. Chem. 2012, 69, 215-230. [CrossRef]

40. Lee, Y.-K.; Woo, J.-S.; Choi, S.-R.; Shin, E.-S. Comparison of Phytoncide (Monoterpene) Concentration by Type of Recreational Forest. J. Environ. Health Sci. 2015, 41, 241-248.

41. Jing, X.; Lun, X.; Fan, C.; Ma, W. Emission Patterns of Biogenic Volatile Organic Compounds from Dominant Forest Species in Beijing, China. J. Environ. Sci. 2020, 95, 73-81. [CrossRef]

42. Kim, B.-U.; Hyun, G.-W.; Choi, J.-H.; Hong, Y.-K.; Yi, G.-H.; Huh, I.-R.; Choi, S.-B. Survey of Emission Characteristics and Weather Factors for Application in Prediction Modeling for Phytoncide Weather Services. J. Environ. Health Sci. 2020, 46, 636-645. 